\title{
Stakeholder Management in the Local Government Decision-Making Area: Evidences from a Triangulation Study with the English Local Government ${ }^{(1)}$
}

\author{
Ricardo Corrêa Gomes* \\ E-mail address: rgomes@ufv.br \\ Universidade Federal de Viçosa \\ Viçosa, MG, Brazil.
}

\begin{abstract}
The stakeholder theory has been in the management agenda for about thirty years and reservations about its acceptance as a comprehensive theory still remains. It was introduced as a managerial issue by the Labour Party in 1997 aiming to make public management more inclusive. This article aims to contribute to the stakeholder theory adding descriptive issues to its theoretical basis. The findings are derived from an inductive investigation carried out with English Local Authorities, which will most likely be reproduced in other contexts. Data collection and analysis is based on a data triangulation method that involves case-studies, interviews of validation and analysis of documents. The investigation proposes a model for representing the nature of the relationships between stakeholders and the decision-making process of such organizations. The decision-making of local government organizations is in fact a stakeholder-based process in which stakeholders are empowered to exert influences due to power over and interest in the organization's operations and outcomes.
\end{abstract}

Key words: public management; local government; strategic management; stakeholder analysis; triangulation methods.

Received 25 April 2005; received in revised form 03 August 2005.

Copyright (C) 2006 Brazilian Administration Review. All rights reserved, including rights for translation. Parts of this work may be quoted without prior knowledge on the condition that the source is identified.

\footnotetext{
* Corresponding author: Ricardo Corrêa Gomes

Travessa Irmã Francisca, 31, Apto 703, Bairro Clélia Bernardes, Viçosa, MG, 36570-000, Brazil. Tel: +55 313892 4687; +55 3187480709.
} 


\section{INTRODUCTION}

The stakeholder theory has been in the management agenda for about thirty years. Since Richard E. Freeman published his landmark book in 1984, several essays have been published aiming to compose the mosaic of this theory. Despite such effort, it is still vague (Jones \& Wicks, 1999) to explain the nature of the relationships between a given organization and the people, groups and other organizations able to participate in its decision-making.

The term stakeholder first "appeared in the management literature in an internal memorandum at the Stanford Research Institute, in 1963” (Freeman, 1984, p. 31). The word means "any group or individual who can affect or is affected by the achievement of the organization's objectives" (Freeman, 1984, p. 46). Bryson (1995, p. 27) proposed a more comprehensive definition for the term: "A stakeholder is defined as any person, group, or organization that can place a claim on an organization's attention, resources, or output or is affected by that output”.

The application of the stakeholder theory in the public sector literature seems to be in accordance with the wave of "New Public Management" (Osborne \& Gaebler, 1993). This body of theory aims to introduce business-based ideas to the public sector. In this vein, the stakeholder theory can be seen as an approach by which public decision-makers scan their environments in search of opportunities and threats.

Looking at the concepts presented above, one can infer that the stakeholder theory embeds two distinct approaches: the organization focusing on its stakeholders in order to propose suitable managerial techniques, and the manner a stakeholder approaches the organization claiming his/her rights. Whilst one side of the coin seems to be related to how an organization behaves when dealing with its stakeholders, the other side seems to be related to how a stakeholder holds the organization accountable to himself/herself. It is clearly a bilateral type of relationship.

The purpose of this article is to examine the nature of the relationships formed between local government organizations and the stakeholders able to participate in their decision-making process by having either power to influence this organization's decision-making or a stake in the organization's operations and outcomes. In doing so the results of an inductive investigation carried out with English Local Authorities are presented. The investigation raised a model for demonstrating the types of stakeholder influences involved in the decision-making process of such organizations. From the model, it is clear that there is a variety of stakeholders capable of influencing, alone or in groups, how decisions are made. This fact implies that these organizations have to be accountable to those stakeholders in some way.

Although based on findings from an Anglo-Saxon context, the findings presented here indicate that the decision-making process of local government organizations attracts multiple stakeholders, which have different interests and amounts of power, from their environments.

\section{THEORIES}

The stakeholder approach was first introduced into the management theory as an answer for dissatisfaction with the unilateral financial criteria of effectiveness. Its roots are found in Richard E. Freeman's book 'Strategic Management: A Stakeholder Approach'. According to him (Freeman, 1984), the main assumption of the stakeholder theory is that an organization's effectiveness is measured by its ability to satisfy not only the shareholders, but also those agents who have a stake in the organization (Freeman, 1984). Since then, many articles have been published that aim to contribute to making this body of knowledge a proper theory. Despite this effort, the stakeholder theory still 
remains vague because it does not explain thoroughly the complexity of the relationships between an organization and the people, groups and other organizations from its environment.

Donaldson and Preston (1995) shed light on this impasse by suggesting that in order to be fully accepted as a theory, the stakeholder theory has to:

. Describe how stakeholders interact with the focal organization;

. "Establish a framework for examining the connections, if any, between the practice of stakeholder management and the achievement of various corporate performance goals” (p. 67);

. Define how the organization needs to deal with its stakeholders in fair and honest relationships.

For a more comprehensive description of the studies which have contributed to the widening of stakeholder theory see Donaldson and Preston (1995). For the moment, it is important to bear in mind that the stakeholder theory is an unfinished body of knowledge that aims to explain the relationships between a given organization and people, groups and other organizations in their environments (there are no specific recommendations in the literature about generalizing stakeholder theory to public organizations).

As the stakeholder theory is an unfinished theory, scholars have been using it in combination with or supported by other theories, such as resource dependence, institutionalism, agency theory, and transaction cost analysis. Oliver (1991) applied resource dependence and institutional theories to identify strategic responses to institutional processes. Greening and Gray (1994) also applied this approach to investigating organizational responses to social and political issues. Both authors have devised their theoretical framework starting from Resource Dependence and Institutionalist perspectives and justified the choice for stakeholder theory as a theoretical bridge for linking the two theories and for categorizing the environmental issues likely to impact an organization's choice (Child, 1976). The main justification is based on the fact that an organization, in order to survive, needs to manage the issues raised in its environment (both technical and institutional). According to them, both theories offer feasible strategic tools to control such adversities.

Employing a different approach, Oliver (1997) used the resource-based theory and institutionalism for supporting stakeholder theory to explain sustainable competitive advantage. Hill and Jones (1992) proposed a stakeholder-agency theory in which an organization's managers are regarded as agents for all the stakeholders involved in the organization's decision-making process. Ruf et al. (2001) employed the stakeholder theory supported by the resource-based theory and transaction cost analysis to explain the relationships between corporate social and financial performances.

Despite accepting that the resource-based theory, the agency theory and the transaction cost analysis can be used supporting the stakeholder theory to explain an organization's behavior and performance, I have opted for resource dependence and institutional theories because they are focused on explaining the environment-organization relationships. The choice was reached by examining at the environmental issues that persuade organizations and stakeholders to relate to each other rather than focusing on resource management (value capture and creation [Bowman, 2000]) or on the form of stakeholder-organization relationship. As stated by Abzug and Webb (1999): "We can think about stakeholder theory as an encompassing (macro) theory that helps to bring institutional, competitive, and dependence forces - and competitive forces - into a unified theory” (p. 420).

\section{Resource Dependence Theory}

As an open system, an organization needs resources and has to negotiate with people, groups and other organizations that own these resources. Depending on the importance of these resources to the organization, this process can lead to a dependency relationship within which resource suppliers are able to exert influences over the organization (Pfeffer \& Salancik, 1978). The higher the relative importance of the resource for the organization, the more attached to this supplier the organization will 
be. Resource Dependence deals with how organizations cope with these dependence relationships in order to survive and retain their autonomy. As Oliver (1991) argued, an organization needs to be fitted with its technical environment in order to be able to cope with interdependencies and power. The more fitted with its technical environment an organization is, the more likely it will be to survive and prosper (Pfeffer \& Salancik, 1978).

Pfeffer and Salancik (1978) argued that dependence is a measurement of how important resource suppliers are to an organization. This measurement might influence the position of the resource supplier in the organization's strategic plan. In Pfeffer and Salancik's view (1978) any component of the technical environment should be, to some extent, important for the organization's survival. It is critical to know how important each one is.

\section{Institutional Theory}

Scott (1998) argues that environmental pressures that make an organization conform to the social and cultural worlds are central to the institutional theory. Within institutional influences, there are some invisible pressures on the organization to adhere to taken-for-granted rules and norms (Oliver, 1991). Meyer and Rowan (1991) argue that, "formal organizations are complex networks of technical relations" this being organizations induced to incorporate taken for granted "rationalized concepts of organizational work and institutionalized in society" (p. 41). These pressures result from the selection process and only adapted organizations will survive (Hannan \& Freeman, 1977).

Organizations often feel threatened by the prospect of being selected out and they decide to be isomorphic with other successful organizations (Hannan \& Freeman, 1977). DiMaggio and Powell (1991, p. 66 as cited Hawley, 1968) defined isomorphism as "a constraining process that forces one unit in a population to resemble other units that face the same set of environmental conditions". For this reason, and being constrained by similar environmental forces, organizations begin to look like each other (Orrù et al., 1991, p. 362).

According to the literature review above, one can link Resource Dependence and Institutional theory together because they focus on different aspects of interorganizational relationships (Oliver, 1990). Resource dependence focuses on the connections created by resource capture and maintenance. At the other end of the scale, institutional theory focuses on the political and moral aspects inherent to this type of relationship. In short, they are two sides of the same coin that are brought together in order to depict the whole picture in which organizations make relations with each other.

\section{Issues in Stakeholder Theory}

By employing resource dependence and institutionalism, the stakeholder theory helps to identify the external people, groups and organizations that claim the organization's attention when preparing its strategic management process. For so doing, Freeman (1984) suggested a method called stakeholder analysis by which an organization is able to scan its environment looking for threats to be avoided or opportunities to be exploited. Several scholars have proposed a methodology for doing so. Among them, Bryson (1995) and Joyce (1999) suggested the following checklist:

. Identification of stakeholders;

. Identification of how stakeholders influence the organization;

. Identification of what the organization needs from each stakeholder;

. Identification of the criteria used by the stakeholder in evaluating the organization; and

. Ranking the stakeholders in a rough order of importance. 
Due to the lack of empirical investigation of stakeholder influences in the local government context, this investigation focuses on the first two steps of the analysis method. Therefore, stakeholder identification is dealt with in order to find out the parameters through which local government organizations ought to identify their stakeholders.

\section{Categories for Stakeholder Identification}

Stakeholders have been classified in two ways. On the one hand, Savage et al. (1991) have argued that stakeholders could be classified as primary or secondary. Primary stakeholders are those who have formal and economic relationships with the organization. Secondary stakeholders are those agents not directly related to the organization despite being able to influence and be influenced by its operation and outcomes. On the other hand, Atkinson et al. (1997) have argued that stakeholders can be seen as environmental or process related. Environmental stakeholders are those included within the external environment in which the organization operates. Other authors classify stakeholders as claimants, influencers or even a combination of both (Kaler, 2002).

Freeman (1984) offered a grid for mapping the organization's stakeholders based on the categories of power and interest, i.e. claimant and influencer. In this model, one dimension relates to the diversity of interests that attracts an external agent to the organization and makes it a stakeholder. The other dimension relates to the power that some agents have to influence an organization's behavior and performance. For the interest dimension, he (Freeman, 1984) suggested three categories, namely equity, economic and 'influencer' interest. On the power dimension, he (Freeman, 1984) suggested that there are external agents that have power over the organization and defined them into three categories: formal, economic, and political power.

Contributing with a general stakeholder identification theory, Mitchell et al. (1997, p. 854) proposed a model based on three dimensions: "(1) the stakeholder's power to influence the firm, (2) the legitimacy of the stakeholder's relationship with the firm, and (3) the urgency of the stakeholder's claim on the firm”. The bases of the three dimensions are dealt with as follows.

\section{Power}

According to Mintzberg (1983), power is the capacity to make someone do what he or she otherwise would not do. He (Mintzberg, 1983) suggested five bases of power:

. Control of resources;

. Control of a technical skill;

. Control of a body of knowledge;

. Power from legal prerogatives; and

Access to those who can rely on the previous sources of power.

Etzione (as cited Mitchell et al., 1997, p. 865) suggested that power is likely to result from three contextual dimensions: normative power, coercive power, and utilitarian power. Normative power results from laws and requirements over which the organization has no control. Coercive power issues from physical means. Utilitarian power results from dependence (Pfeffer \& Salancik, 1978), because the organization has to behave against its own will in order to achieve resources.

Hardy (1996 as cited Lukes, 1974) suggests that power stems from resources, processes and meaning. The first dimension of power is derived from the ownership of resources. People who own some type of resources are more likely to coerce others into behaving according to their will. For example, "information, expertise, political access, credibility, stature and prestige, access to higher echelon members, the control of money, rewards and sanctions” (Hardy,1996, p. S7). Pfeffer and 
Salancik (1978) employed this concept of power to explain dependency. Power also stems from the decision-making process, and people who have domination over such processes are entitled to coerce others by applying or not applying "procedures and political routines" (Hardy, 1996, p. S7). The third dimension of power relates to the power to prevent "conflict from emerging in the first place" (Hardy,1996, p. S8). That is, some people have control over the status quo and in doing so they can suppress others from their cognition. These two bases of power can also be related to the environmental influences over organizations to the extent that political and professional issues arise from their pressuring the organization to comply with their requirements.

Enhancing this view, (Daake, 2000, p. 94) suggests that:

Stakeholders can impact the strategic planning process in two important ways. First, certain stakeholders may demand or be invited to participate in the planning process itself. Second, even though some stakeholders may not be a direct part of the strategic planning process, their interests are clearly considered as part of the scanning process (p. 94).

\section{Urgency}

Mitchell et al. (1997) argues that urgency has many meanings, but in terms of stakeholder management it can be seen as a result of time sensitivity and criticality. In other words, a stakeholder is said to have urgency in a situation where his/her demands have to be dealt with in a short time otherwise the organization will be in serious trouble.

\section{Legitimacy}

Mitchell et al. (1997) regardes this dimension as critical to a stakeholder's identification. Sometimes an actor has a stake in the organization but this demand is neither legal nor moral. They (Mitchell et al., 1997) also suggests that only actors who have legitimalte stakes are to be regarded as proper stakeholders. Mitchell et al. (1997, p. 866) define legitimacy as "a generalized perception or assumption that the actions of an entity are desirable, proper, or appropriate within some socially constructed systems of norms, values, beliefs, and definitions”.

\section{Methods}

The research focus is placed in the English system of local government, in which these are agencies for delivering services to the local population. The investigation took place over the period of July 2001 to February 2002. The methodology used data triangulation analysis (Denzin, 1970) from three types of sources: cross-sectional case studies, interviews of validation and analysis of documents.

Multiple and embedded case studies (Yin, 1994) were undertaken with four English Local Authorities: the District Councils of Braintree and South Northamptonshire, the London Borough of Hackney and the Metropolitan District of Calderdale. These authorities were chosen from a list of 18 which had previously demonstrated interest in participating in the study. They were chosen due to their characteristics for representing the whole population into a two-dimension model, namely the political context and geographic differences. Table 1 illustrates this matter. Political context is a variable for representing the ideology controlling the authority at the moment of the investigation. Geographical difference is a variable for representing the physic and demographic differences among local authorities. I decided to use the Countryside Agency classification that classifies authorities as rural and non rural. The four cases are described as follows.

Located in the Greater London area, the London Borough of Hackney had, at the time of the investigation, a population of 193,843 inhabitants (Municipal Year Book, 2002, p. 450) and occupies an area of 1,950 hectares (Municipal Year Book, 2002). Its council was composed of 60 councilors with the following composition: 32 Labour, 15 Liberal Democrats, 11 Conservatives, and 2 Green. 
Elections in Hackney are undertaken on a four year cycle for the whole council (Municipal Year Book, 2002).

Located in Yorkshire and Humber, the Metropolitan District of Calderdale appeared as a result of the Local Reorganization of 1974 (Municipal Year Book, 2002, p. 176). At the time of the investigation, it had a population of 193,000 inhabitants and it occupies an area of 36,346 hectares (Municipal Year Book, 2002, p. 173). Elections in Calderdale are held to form a third of the council. Calderdale council was composed made up of 54 councilors, whose political composition was 28 Conservatives, 15 Liberal Democrats, 10 Labour and 1 Independent. Figure 10 shows Calderdale's location within the region of Yorkshire and Humber. It is represented by area number 3 .

The District Council of Braintree is located in Essex County Council. At the time of the investigation, it had a population of 132,294 inhabitants and it occupies an area of 61,206 hectares (Municipal Year Book, 2002, p. 126). Elections in Braintree are held for the whole council. Braintree council was composed by 60 councilors with the following political composition: 31 Labour, 17 Conservatives, 4 Independents, 3 Liberal Democrats, 3 R. and 2 Green. The figure below shows the region of Essex in which area number 4 represents Braintree.

Located in Northamptonshire County Council, the South Northamptonshire District Council had, at the time of the investigation, a population of 79,440 inhabitants and it occupies an area of 63,156 hectares (Municipal Year Book, 2002, p. 953). The council was composed of 42 councilors (Municipal Year Book, 2002, p. 955) with the following political composition: 29 Conservatives, 6 Labour, 4 Independents and 3 Liberal Democrats (Municipal Year Book, 2002, p. 956). Elections in South Northamptonshire are undertaken on a whole council basis (Municipal Year Book, 2002, p. 953). The figure below shows the location of the district in the East Midlands' map in which area number 38 represents South Northamptonshire.

Table 1: Cases of Research

\begin{tabular}{|c|c|c|c|}
\hline & & \multicolumn{2}{|c|}{ Political Context } \\
\hline & & Labour & Conservative \\
\hline \multirow{2}{*}{$\begin{array}{l}\text { Geographical } \\
\text { Differences }\end{array}$} & Rural & $\begin{array}{c}\text { Braintree District } \\
\text { Council }\end{array}$ & $\begin{array}{c}\text { South Northamptonshire } \\
\text { District Council }\end{array}$ \\
\hline & Non-rural & $\begin{array}{l}\text { London Borough } \\
\text { of Hackney }\end{array}$ & $\begin{array}{l}\text { Metropolitan District } \\
\text { of Calderdale }\end{array}$ \\
\hline
\end{tabular}

Source: Data Findings.

In each case study, officers and councilors were interviewed about decision-making and stakeholders involved in the process. Due to the variety and multiplicity of services provided by local governments, the investigation focused on the Waste Collection Services. The interviews were recorded and transcribed afterwards. In order to enhance the construct validity (Yin, 1994), the interviewees were confronted with the analysis of the Best Value Performance Plan, which is a document that is published every year by every single local authority in Britain according to the Best Value requirements (Department of the Environment Transport and the Regions - DETR, 1998).

The interviews of validation were undertaken with key informants within the English local government context and they were key stakeholders, groups of reference and scholars with an acknowledged contribution to the field. In this process, data was gathered through face to face and electronic interviews, which were also recorded and transcribed. 
The analysis of documents was carried out with the legal framework issued by central government since 1997 (the time the Labour Party took office). These documents are:

- Local Government Act 1999, which was issued in August 1999 and by which the Best Value scheme came in force in Britain;

. Local Government Act (LGA) 2000 whereby the New Councilors Constitution scheme was introduced into Great Britain;

- Strong Local Leadership: Quality Public Services - a white paper issued by the Government in December 2001, which according to the Prime Minister's introductory words, "seeks to establish a partnership between central and local government, reflecting the critical importance of local authorities as a tier of democratic government, delivering high quality public services to local people.” (Foreword);

. Local Strategic Partnership: Government Guidance - issued in March 2001 by the DETR;

. Waste Strategy 2000: for England and Wales issued in May 2000 by the DETR. This document aimed to set the main agenda in terms of Waste in Britain;

Whilst case studies provided the design of the current decision-making process employed by English local authorities, interviews of validation and analysis of documents provided the support for accepting the process as a genuine representation of decision-making employed by this type of organization.

The data collection process provided a massive amount of accounts and documents which have been analyzed by the 'Partially Ordered Meta Matrix' process for analyzing texts and documents (Miles \& Huberman, 1994). This tool consists of fragmenting data into the smallest possible units in order to find "common codes, common displays of commonly coded data segments, and common reporting formats for each case" (Miles \& Huberman, 1994, p. 178). The whole process was carried out with the help of the NUDIST software, which according to Miles and Huberman $(1994$, p. 312) is the tool that enables the content analysis of texts by fragmenting it into "segments or chunks" and is an accepted tool for the theory building process.

The investigation employed the NUDIST to scan the texts looking for evidence concerning stakeholder influences. The data analysis process detected that there are some stakeholders causing an active influence because they objectively represent power and interest in decision-making. This evidence is based on the fact that these stakeholders are referred to in the active voice (e.g. central government sets the agenda). Other stakeholders have passive influence in the extent that they need to be engaged in decision-making (e.g. the local community has to be involved). When identified, the influences were clustered.

\section{Findings}

The triangulation analysis indicated that stakeholder influences in local government decision-making can be classified into three categories:

. The nature of the participation in decision-making;

. The basis of the participation; and

- The sources of influence.

The first category indicates the nature of stakeholder participation in decision-making. It is active (i.e. by influencing) or passive (i.e. by being influenced). The second category defines the basis of the influence and is based on Freeman's power/interest dimensions. The third category indicates where the environment stakeholder influences come from. The table below illustrates the three categories. 
Table 2: A Proposed Taxonomy for Understanding Stakeholder Influences

\begin{tabular}{|c|c|c|c|}
\hline $\begin{array}{c}\text { Type 1: } \\
\text { The nature }\end{array}$ & & $\begin{array}{l}\text { Type 2: } \\
\text { The basis }\end{array}$ & $\begin{array}{c}\text { Type 3: } \\
\text { The source }\end{array}$ \\
\hline $\begin{array}{ll}\checkmark & \text { Power } \\
\checkmark & \text { Influence }\end{array}$ & $\begin{array}{l}\quad \text { Sources of interest: } \\
\checkmark \text { Community interest } \\
\checkmark \text { Ownership } \\
\checkmark \text { Trading }\end{array}$ & $\begin{array}{l}\text { Sources of Power: } \\
\checkmark \text { Control over Resources } \\
\checkmark \text { Control over Skills/knowledge } \\
\checkmark \text { Legal Prerogatives }\end{array}$ & $\begin{array}{ll}\checkmark & \text { Institutional } \\
\checkmark & \text { Technical }\end{array}$ \\
\hline
\end{tabular}

Source: Adapted from Freeman (1984); Mintzberg (1983); Hardy (1996); Scott (1998).

The taxonomy above led to the identification of eight stakeholder influence clusters from which influences are exerted on decision-making. It is a significant normative contribution to stakeholder identification theory. This evidence indicates that, in the local government context, stakeholder influences come about in clusters through which different stakeholders are likely to exert similar influences. This introduces a new approach in stakeholder management because managers would be able to set the same strategy for dealing with different stakeholders.

The table below presents the analysis done in this study. It is split into two main columns: one column presents the Partially Ordered Meta Matrix analysis and a second column presenting the taxonomy analysis in which stakeholder influences are better understood in the light of the theoretical framework proposed.

The clusters of influence detected in this investigation are presented as follows.

Table 3: The Clusters of Stakeholder Influence

\begin{tabular}{|c|c|c|c|c|}
\hline \multicolumn{2}{|c|}{ Stakeholder Influences } & \multicolumn{3}{|c|}{ Classification } \\
\hline Stakeholder & Influence/interest & Type 1 & Type 2 & Type 3 \\
\hline \multicolumn{5}{|c|}{ Cluster 1: Decision-Makers } \\
\hline \multirow[t]{2}{*}{ Senior officers } & Implement policies & \multirow[t]{2}{*}{ Power } & \multirow[t]{2}{*}{ Control over skills } & \multirow[t]{2}{*}{ Technical } \\
\hline & Manage services & & & \\
\hline \multirow{7}{*}{ Councillors } & Approve policies & \multirow{6}{*}{ Power } & \multirow{6}{*}{ Legal prerogative } & \multirow{6}{*}{ Technical } \\
\hline & Delegate responsibilities & & & \\
\hline & Monitor performance & & & \\
\hline & Implement policies & & & \\
\hline & Lead the council & & & \\
\hline & Make decisions & & & \\
\hline & Represent community & Power & Legal prerogative & Institutional \\
\hline Senior officers & Make delegated decisions & Power & Legal prerogatives & Technical \\
\hline \multicolumn{5}{|c|}{ Cluster 2: Agenda Setting } \\
\hline \multirow{3}{*}{ Local businesses } & Are consulted, are listened & \multirow{3}{*}{ Interest } & \multirow{3}{*}{ Customer } & \multirow{3}{*}{ Technical } \\
\hline & Are encouraged, are involved & & & \\
\hline & Are informed, are reported & & & \\
\hline
\end{tabular}




\begin{tabular}{|c|c|c|c|c|}
\hline & Express themselves & & & \\
\hline \multirow{8}{*}{ Local residents } & Are consulted, are listened & \multirow{8}{*}{ Interest } & \multirow{8}{*}{ Customer } & \multirow{8}{*}{ Technical } \\
\hline & Are encouraged, are involved & & & \\
\hline & Are informed, are reported & & & \\
\hline & Are service users & & & \\
\hline & Have needs & & & \\
\hline & Have to be satisfied & & & \\
\hline & Place requirements & & & \\
\hline & Show low interest level & & & \\
\hline \multirow{2}{*}{$\begin{array}{ll}\text { Tie } & \text { Related } \\
\text { Councils } & \end{array}$} & Are accounted, are informed & \multirow[t]{2}{*}{ Interest } & \multirow[t]{2}{*}{ Customer } & \multirow[t]{2}{*}{ Institutional } \\
\hline & Are consulted & & & \\
\hline $\begin{array}{l}\text { Central } \\
\text { Government }\end{array}$ & Sets the overall agenda & Power & Ownership & Institutional \\
\hline Council & Sets the local agenda & Power & Ownership & Institutional \\
\hline \multicolumn{5}{|c|}{ Cluster 3: Decision-Making Facilitators } \\
\hline \multirow{5}{*}{ Senior officers } & Advice councillors & \multirow{5}{*}{ Power } & \multirow{5}{*}{ Control over skills } & \multirow{5}{*}{ Technical } \\
\hline & Drive the agenda & & & \\
\hline & Elaborate businesses plans & & & \\
\hline & Make recommendations & & & \\
\hline & Propose policies & & & \\
\hline \multirow[t]{2}{*}{ Employees } & Are consulted & \multirow[t]{2}{*}{ Power } & \multirow[t]{2}{*}{ Control over skills } & \multirow[t]{2}{*}{ Technical } \\
\hline & Are involved & & & \\
\hline \multicolumn{5}{|c|}{ Cluster 4: Performance Developers } \\
\hline \multirow{4}{*}{ LGA } & Advises local governments & \multirow{4}{*}{ Interest } & \multirow{4}{*}{ Community Interest } & \multirow{4}{*}{ Institutional } \\
\hline & Represent local governments & & & \\
\hline & Tries to arrange more money & & & \\
\hline & Tries to ease the legal framework & & & \\
\hline \multirow{4}{*}{ IDEA } & Examines all councils do & \multirow{4}{*}{ Power } & \multirow{4}{*}{ Control over skills } & \multirow{4}{*}{ Technical } \\
\hline & Helps to shape the policy & & & \\
\hline & Reports inspections & & & \\
\hline & Reviews performance & & & \\
\hline $\begin{array}{l}\text { The Audit } \\
\text { Commission }\end{array}$ & Makes recommendations & Power & Legal prerogative & Institutional \\
\hline \multicolumn{5}{|c|}{ Cluster 5: Decision-Making Legitimisers } \\
\hline \multirow[t]{2}{*}{ Local residents } & Are represented & & & \\
\hline & Elect the council & Power & Legal prerogatives & Institutional \\
\hline & Cluster 6: Decision- & king Co & ollers & \\
\hline & Does not press the council & & & \\
\hline & Informs the population & & & \\
\hline & $\begin{array}{l}\text { Publicises the council's } \\
\text { arrangements }\end{array}$ & & & \\
\hline
\end{tabular}




\begin{tabular}{|c|c|c|c|c|}
\hline \multirow[t]{3}{*}{ Local Media } & Publishes performance indicators & \multirow[t]{3}{*}{ Power } & \multirow[t]{3}{*}{ Control over resources } & \multirow[t]{3}{*}{ Institutional } \\
\hline & Scrutinises councillors' decisions & & & \\
\hline & Transmits information & & & \\
\hline \multirow{7}{*}{$\begin{array}{l}\text { The Audit } \\
\text { Commission }\end{array}$} & Assesses performance & \multirow{7}{*}{ Power } & \multirow{7}{*}{ Legal prerogative } & \multirow{7}{*}{ Institutional } \\
\hline & Audits processes & & & \\
\hline & Can embarrass the council & & & \\
\hline & Creates PIs & & & \\
\hline & Demands information & & & \\
\hline & Inspects services & & & \\
\hline & Publishes performance & & & \\
\hline $\begin{array}{l}\text { Central } \\
\text { Government }\end{array}$ & Controls performance & Interest & Ownership & Technical \\
\hline \multicolumn{5}{|c|}{ Cluster 7: Delivering Services } \\
\hline \multirow{3}{*}{ Employees } & Are to be developed & \multirow{3}{*}{ Power } & \multirow{3}{*}{ Control over skills } & \multirow{3}{*}{ Technical } \\
\hline & Are to be encouraged & & & \\
\hline & Are to be valued & & & \\
\hline \multirow{5}{*}{ Voluntary Sector } & Acknowledge the council & \multirow{5}{*}{ Interest } & \multirow{5}{*}{ Customer } & \multirow{5}{*}{ Technical } \\
\hline & Are consulted & & & \\
\hline & Are partners & & & \\
\hline & Are service deliverers & & & \\
\hline & Co-operate with the authority & & & \\
\hline \multirow{5}{*}{ Public Partners } & Are accounted, are informed & \multirow{5}{*}{ Interest } & \multirow{5}{*}{ Customer } & \\
\hline & Are consulted & & & \\
\hline & Are involved & & & Technical \\
\hline & Are partners & & & \\
\hline & Are service delivers & & & \\
\hline \multirow{5}{*}{ Private partners } & Are consulted & \multirow{5}{*}{ Interest } & \multirow{5}{*}{ Customer } & \\
\hline & Are regarded & & & \\
\hline & Co-operate with the council & & & Technical \\
\hline & Influence the councillors & & & \\
\hline & Have to be monitored & & & \\
\hline \multicolumn{5}{|c|}{ Cluster 8: Defining Policy Frameworks } \\
\hline Central Government & Sets the legal framework & Power & Legal prerogative & Institutional \\
\hline \multirow[t]{2}{*}{ Councillors } & Set the budget & \multirow[t]{2}{*}{ Power } & \multirow[t]{2}{*}{ Legal prerogative } & \multirow[t]{2}{*}{ Institutional } \\
\hline & Set down local policies & & & \\
\hline Central Government & Allocates money & Power & Control over resources & Institutional \\
\hline Local residents & Pay taxes & Power & Customer & Technical \\
\hline
\end{tabular}

Source: Data findings. 


\section{Decision-makers}

In this cluster, the presence of stakeholders who aim to keep the decision-making process running was detected. According to the findings, the main influential stakeholders are the councilors who are empowered to make the most important decisions within the council and their decisions are supported by the skill and expertise of senior officers and staff.

The influences detected in this cluster are all regarded as a representation of power upon decisionmaking. They differ in terms of the basis upon which influences are exerted as the table indicates. Councilors' powers stem from legal prerogatives and senior officers' powers derive from their control over skills/knowledge

Influences generated by this cluster originated from both technical and institutional environments.

\section{Agenda Developers}

In this cluster, central government and the full council were identified as the main influencers. The influence generated in this cluster is acknowledged as active. Both central government and the full council have ownership interest to set the agenda under which local authorities are to be steered. In addition, both have the power to influence decision-making because they are empowered by legal requirements to do so. Influences generated from this cluster are institutionally-based.

\section{Decision-Making Facilitators}

In this cluster, senior officer and employees were identified to be able to influence decision-making. It is an active influence and both have the power to influence because they control the required skills that councilors rely upon for making decisions. Moreover, influences generated from this cluster are technically-based.

\section{Performance Developers}

In this cluster, the Audit Commission, the LGA, and the IDeA were identified as being able to exert influence in decision-making. Influences generated from this cluster are active and they are stems from both technical and institutional environments. The Audit Commission is empowered by legal requirement to create conditions for improving local government performance. The LGA and the IDeA have community interests in decision-making. The IDeA's role is due to its objectives as an agency created by local government to help local government.

\section{Decision-Making 'Legitimisers'}

In this cluster, citizens (exercising their voting-rights) were identified as the only stakeholders empowered to influence decision-making. Influences generated from this cluster are active and institutional. As citizens elect councilors to make decisions on their behalf, they have ownership interest in the process.

\section{Decision-Making Controllers}

In this cluster, central government, the Audit Commission, councilors, and the local media were identified as influencers in decision-making. Central government is influential due to its power resources (funds), which is a technical influence. The Audit Commission is legally empowered to oversee local government's behavior and performance from laws and is an institutional influence. The full council is empowered by law to scrutinize decision-making. To do so, it indicates members to compose the scrutiny committee. According to the Local Government Act 2000 (DETR, 2000), the 
scrutiny committee is a body empowered to scrutinize the executive committee in the implementation of policies and frameworks set by the whole council. It is therefore an institutional influence.

Lastly, the local media is able to scrutinize decision-making because it has control over the critical resource of information. Therefore, it is a technical influence.

\section{Service Deliverers}

In this cluster, some stakeholders were identified as being able to exert influence because they help to deliver services. They are employees, voluntary organizations, public partners and private partners. These stakeholders have power to influence decision-making because they control skills that characterize the influence as technical. There is another influence identified in this cluster which stems from the concept of isomorphism. As organizations compete and co-operate with local government delivering services, they are likely to influence mimetic isomorphism over it. For this reason, a type of institutional and passive influence can be identified as stemming from this cluster.

(In this cluster, stakeholders have been identified who are able to exert influence because they help in delivering services. They are employees, voluntary organizations, public partners and private partners. These stakeholders have the power to influence decision-making because they control skills which characterize it is a technical influence. There is another influence identified in this cluster which stems from the concept of isomorphism. As organizations compete and co-operate with local government delivering services, they are likely to influence mimetic isomorphism over it. For this reason, a type of institutional and passive influence can be identified as stemming from this cluster.)

\section{Policy-Framework Developers}

In this cluster, central government, the full council and local taxpayers were identified as influential stakeholders. The first two stakeholders have power because they are legally institutionalized to do so. They have the power to define the legal and financial framework within which decisions are to be made. Therefore, it is a type of institutional influence.

The local taxpayers have power because they control financial resources, which is therefore a type of technical influence. According to the findings, it is not a strong influence due to the funding system employed in Britain in which around $70 \%$ of the money spent by local government comes from central government.

Figure 1 presents the power-influence model. As councilors are the 'leaders' of the process, they have the final word in decision-making. In this way, and trying to shape the model, the decisionmaking process in action (clusters in which decision-makers are inserted) has to be at the centre of the system being surrounded by the other 'bodies'. The model is built upon an analogy with the solar system, in which the sun is at the centre and the other planets are attracted to it by the force of gravity.

Each cluster is connected to the centre by an arrow which represents the influence communication channel. The golden rectangles surrounding the decision-making box represent the clusters of influences. The pale yellow and dotted boxes represent the stakeholders entitled to exert that sort of influence. These boxes are dotted due to stakeholder concept, which embeds a notion of flexibility since stakeholders are likely to change according to different environmental conditions. The pale blue rectangles represent the sort of influence transferred through the arrows. The model summarizes the findings concerning stakeholder identification and salience in the decision-making process of English Local Authorities. 


\section{CONCLUSION}

This study sought to identify the relationships between local governments and their stakeholders. This was done through an inductive investigation with English Local Authorities. Data upon which the analysis was carried out comes from cross-sectional case studies, interviews of validation and analysis of documents. Data is analyzed by 'Partially Ordered Meta Matrix' in which narratives are split into units that are as small as possible in order to identify patterns of relationships.

As a result of the data analysis process, a power-influence model has been built up in which a stakeholder's participation in local government decision-making is depicted. As a descriptive/empirical contribution to the stakeholder theory, the model indicates a set of stakeholder influences that are both technicallly and institutionally-based. Influences stem from both powers and interests which induce a stakeholder to participate in this process. By pointing out clusters of influences, the model also raises an instrumental contribution to stakeholder management because it identifies alternatives for dealing with stakeholders either as individuals or groups. Finally, the model indicates the whole set of categories representing stakeholder influences for which local government has to be held accountable.

This study provides a solid basis for further investigations involving stakeholder management in local government. Even though based on evidence from an Anglo-Saxon context, the paper offers a theoretical and methodological framework to be applied in other contexts. By employing the model, scholars are likely to identify managerial tools for dealing with stakeholders due to their power to influence the organization as well as their interest in doing so. They can also use the model as a basis to explore the relations between local government performance and stakeholder influences providing instrumental contributions to stakeholder theory. 

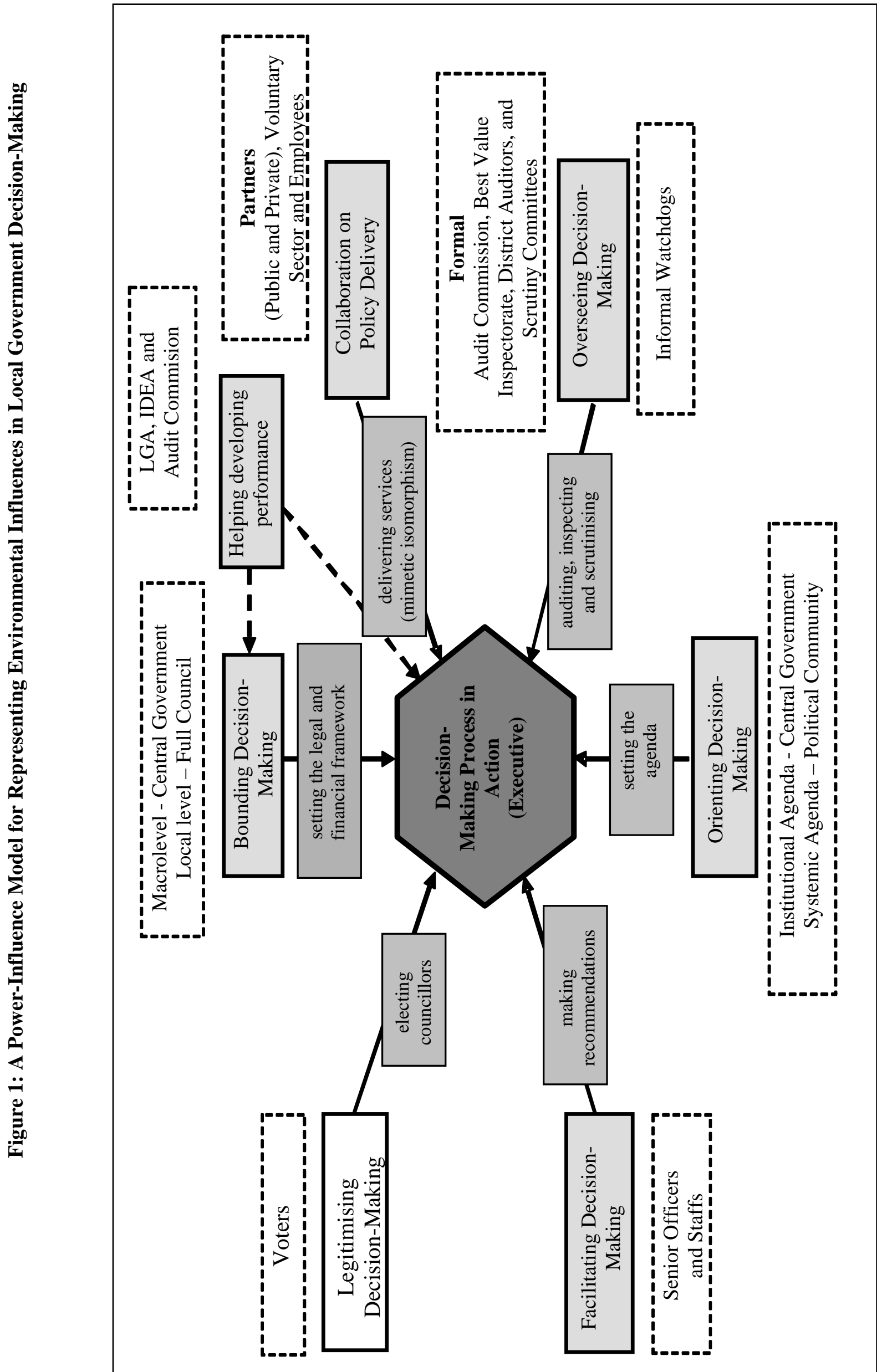


\section{NOTE}

\footnotetext{
${ }^{1}$ This research was funded by CAPES.
}

\section{REFERENCES}

Abzug, R. \& Webb, N. (1999, December) Relationships between nonprofit and for-profit organizations: a stakeholder perspective. Nonprofit and Voluntary Sector Quarterly, 28(4), 416431.

Atkinson, A. A., Waterhouse J. H. \& Wells, R. B. (1997, Spring). A stakeholder approach to strategic performance measurement. Sloan Management Review, 38(3), 25-37.

Bowman, C., \& Ambrosini, V. (2000, December). Value creation versus value capture: towards a coherent definition of value in strategy. British Journal of Management, 11, pp. 1-15.

Bryson, J. (1995). Strategic planning for public and non-profit organization (Rev. Ed.). San Francisco: Jossey-Bass Publishers.

Child, J. (1976). Organisation design and performance: contingency theory and beyond. Birmingham: Aston University.

Daake, D., \& Anthony, W. P. (2000, Summer). Understanding stakeholder power and influence gaps in a health care organization: an empirical study. Health Care Management Review, 25(3), 94-107.

Denzin, N. K. (1970). The research act in sociology: a theoretical introduction to sociological method. London: Butterworth \& Co.

Department of the Environment Transport and the Regions - DETR (1998). Modernising local government: improving local services through best value. London: Author.

Department of the Environment Transport and the Regions (2000). New councils constitution: guidance pack volume 1. London: Author.

DiMaggio, P. J., \& Powell, W. W. (1991). The iron cage revisited: institutional isomorphism and collective rationality in organizational fields. In W. W. Powell, \& P. J. DiMaggio (Eds.). The new institutionalism in organizational analysis. Chicago: The University of Chicago Press.

Donaldson, T., \& Preston. L. E. (1995, January). The stakeholder theory of the corporation: concepts, evidences, and implications. Academy of Management Review, 20(1), 65-91.

Freeman, R. E. (1984). Strategic management: a stakeholder approach. Massachusetts: Pitman. 
Greening, D. W., \& Gray. B. (1994, March). Testing a model of organizational response to social and political issues. Academy of Management Journal, 37(3), 467-498.

Hannan, M. T., \& Freeman. J. (1977, Spring). The population ecology of organizations. American Journal of Sociology, 82(5), 929-964.

Hardy, C. (1996, March). Understanding power: bringing about strategic change. British Journal of Management, 7(special issue), S3-S16.

Hawley, A. (1968). Human Ecology. In D. L. Sills (Ed.) International encyclopedia of the social sciences. New York: Macmillan.

Hill, C., \& Jones, T. M. (1992, March). Stakeholder-agency theory. Journal of Management Studies, 29(2), 131-154.

Jones, T. M., \& Wicks, A. C. (1999, April). Convergent stakeholder theory. Academy of Management Review, 24(2), 206-221.

Joyce, P. (1999). Strategic management for the public services. Philadelphia: Open University Press.

Kaler, J. (2002, August). Morality and strategy in stakeholder identification. Journal of Business Ethics, 39(1/2), 91-99.

Meyer, J. W., \& Rowan, B. (1991). Institutionalized organizations: formal structure, myth, and ceremony. In W. S. Powell, \& P. J. DiMaggio (Eds.). The new institutionalism in organizational analysis. Chicago: The University of Chicago Press.

Miles, M. B., \& Huberman, A. M. (1994). Qualitative data analysis: an expanded sourcebook. Thousand Oaks: Sage Publications.

Mintzberg, H. (1983). Power in and around organizations. New Jersey: Prentice Hall, Inc.

Mitchell, R. K., Agle B. R. \& Wood, D. J. (1997, October). Toward a theory of stakeholder identification and salience: defining the principle of the who and what really counts. Academy of Management Review, 22(4), 853-886.

Municipal Yearbook and Public Services Directory. (2002). Municipal year book and public services directory (Vol. I-II). London: Hemming Information Services.

Oliver, C. (1990, April). Determinants of Interorganizational Relationships: Integration and Future Directions. Academy of Management Review, 15(2), 241-265.

Oliver, C. (1991, January). Strategic responses to institutional processes. Academy of Management Review, 16(1), 145-179.

Oliver, C. (1997, October). Sustainable competitive advantage: combining institutional and resourcebased views. Strategic Management Journal, 18(9), 697-713.

Orrù, M., Briggart, N. W., \& Hamilton, G. G. (1991). Organizational isomorphism in East Asia. In W. S. Powell, \& P. J. DiMaggio (Eds.). The new institutionalism in organizational analysis. Chicago: The University of Chicago Press.

Osborne, D., \& Gaebler, T. (1993). Reinventing government: how the entrepreneurial spirit is transforming the public sector from schoolhouse to statehouse, city hall to the Pentagon. Reading, MA: Addison-Wesley. 
Pfeffer, J., \& Salancik, G. R. (1978). The external control of organizations: a resource dependence perspective. New York: Harper and How.

Ruf, B. M., Muralidhar, K., Brown, R. M., Janney, J. J., \& Paul, K. (2001, July) An empirical investigation of the relationship between change in corporate social performance and financial performance: a stakeholder perspective. Journal of Business Ethics, 32(2), 143-156.

Savage, G. T., Nix, T. W., Whitehead, C. J., \& Blair, J. D. (1991, May). Strategies for assessing and managing organizational stakeholders. Academy of Management Executive, 5(2), 61-75.

Scott, W. R. (1998). Organizations rational, natural, and open systems (4th ed.). New Jersey: Prentice-Hall Inc.

Yin, R. K. (1994). Case Study Research, design and methods (2nd ed.). Thousand Oaks: Sage Publications. 